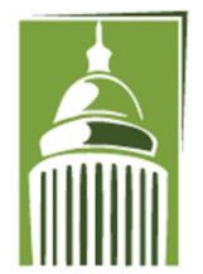

AR F

\section{Global Proceedings Repository \\ American Research Foundation}

ISSN 2476-017X

Available online at http://proceedings.sriweb.org

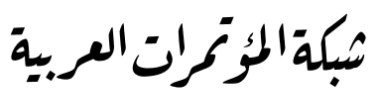

http://arab.kmshare.net/

The 10th International Scientific Conference

Under the Title

"Geophysical, Social, Human and Natural Challenges in a Changing Environment"

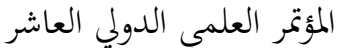

$$
\begin{aligned}
& \text { تحت عنوان "التحديات الجيوفيزيائية والاجتماعية والانسانية والطبيعية في بيئة متغيرة" } \\
& 25 \text { - } 26 \text { يوليو - تموز } 2019 \text { - اسطنبول - تركيا }
\end{aligned}
$$

http://kmshare.net/isac2019/

\title{
Description, Antifungal Activities Designed for Ocimum sanctum in Green Produced Silvery Nanoparticles
}

\author{
${ }^{1}$ Intesar Ali Mezeal , ${ }^{2}$ Ghanyia Jasim Shanyoor , ${ }^{3}$ Sabreen Ali Mezil \\ ${ }^{1,2}$ Department of Biology , College of Science, Mustansiriyah University, Baghdad, Iraq \\ ${ }^{3}$ Department of Medical Instrumentation Engineering, Al-Hadi University College, Baghdad, Iraq \\ E-mail: intesarali664@uomustansiriyah.edu.iq
}

1. Abstract: Silver Nanoparticles designated for instance inhibitor apparatus on numerous pathogenic mycological straining. In this examination comprised investigation of Ocimum sanctum excerpt besides Bio combination of Silver Nanoparticles by Ocimum sanctum in contradiction of 10 pathogenic molds contain ( F. circinatum ,B. Curvularia, M. oryzae, P. asparagicola, , A. flavus, R. oryzae, Penicillium digitatum, G. amycelicum,M. limbalis, Alternate alternate) amalgamation of AgNPs inspected through modification of pigment (exhibition yellow to brown ) besides approval of Silver Nanoparticles amalgamation UV-Vis spectroscopy oppressed intended for terminus at captivation (400-430) $\mathrm{mm}$. Consequences presented alterations in antifungal activities of Silver Nanoparticles diagonally practiced molds besides frequent attentions. Among the practiced fungi, extreme reserve proportion $(96.1,94.2,93.5 \%)$ experimental by ( R. oryzae, A.niger and A. alternata ) correspondingly on $300(\mathrm{mg} / \mathrm{ml})$ from Silver Nanoparticles, while bottommost inhibition proportion $(11.9,14.7,17.3 \%)$ perceived by (Phomopsid asparagicola, Penicillium digitatum, Magnaporthe limbalis) 


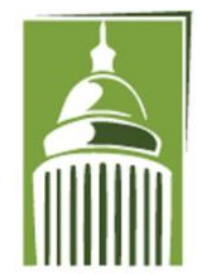

AR F
Global Proceedings Repository

American Research Foundation

ISSN 2476-017X

Available online at http://proceedings.sriweb.org

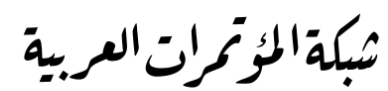

http://arab.kmshare.net/

individually

in $50(\mathrm{mg} / \mathrm{ml})$ from Silver

Nanoparticles

Key words: Silver Nanoparticles, , anti fungal, Ocimum sanctum, amalgamation , UV-Vis spectroscopy .

\section{2-Overview}

Nanoparticle is a constituent part by size in variety of (1-100) $\mathrm{nm}(1)$. That inclination toward reply contrariwise than bigger particles of similar preparation for the reason that their big superficial space, so letting them to remain secondhand in dissimilar proposals (2). Also, contribution by way of significant construction lump of Nano technology (3).Now here is widespread submission of Nano particles happening diverse turfs including (catalysis, dynamism, medicine besides chemistry) (1). Nano technology approaches toward regulator infection in hominid and floras must recently remained increasing prominently and singular physicochemical belongings of Nano sized metallic atoms product them productive in natural science in addition medication (4). The current understanding of conceivable endangerments connected with declaration of resources in environs used for humanoid, animal fitness is motionless lacking ( 5). Amalgamation of Nano particles consumes changed a substance of uncountable courtesy owing to varied valuable properties besides requirements in assortment of arenas (6). Many procedures have remained upcoming to create metal Nano particles, counting (Electro-chemical, sono -chemical, besides photo chemical) methods, however, supreme of these approaches offended beginning the practice of poisonous, precarious chemicals besides distress in decontamination (7). The practice of floras besides microorganisms in amalgamation of Nano particles consumes currently cast-off used for frequent reasons .The chief goal is environmentally, naturally inoffensive and contribution as innocuous nan- works, added goals is they a smaller custody and inoffensive for human beneficial custom $(8,9)$. It honestly important to opinion out many microbes is hygienically endangerment to completely corporeal beings, besides conservation necessity be engaged to explanation for production NPs. That uncovered unquestionable plants must ability on the way to formula NPs that presentation as toxic resources like metallic ions(10). Plant intervened organic amalgamation of NPs is accomplishment standing 


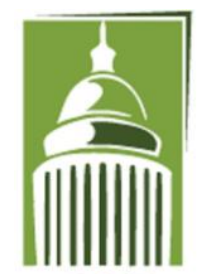

AR F
Global Proceedings Repository

American Research Foundation

ISSN 2476-017X

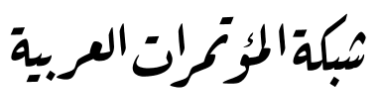

http://arab.kmshare.net/

Available online at http://proceedings.sriweb.org

owing to its confidence and Eco friendliness. However bio synthesis of silver NPs using plants like neem (11 ), Aloe (12), Moldavian Dragonhead (13), bitter melon (14), Cats hair (15) and Tamarind (16) were designated, the conceivable of plants such as natural resources for amalgamation of NPs is until now to remain totally revealed. Silver NPs have complicated focused examination courtesy for the reason that of their authoritative proposals as catalytic, anti-microbial besides surfaceenhanced Raman minority consequence (17).

Silver has remained secondhand by way of anti-microbial mediator for periods, the new-fangled rebirth in care to this component primarily courtesies on increasing danger of anti-biotic confrontation, prompted through exploitation to anti-biotics (18). That typically recognized that silver NPs might credit to cell wall, so worrying cell-wall porousness and cellular sigh. NPs may well similarly enter inside cell manufacturing damage through interconnecting with phosphorus and sulfur comprising amalgams like (DNA, protein). Additional imaginable effect to bactericidal possessions of Silvery Nanoparticles that include statement of Ag+ of units (19). Frequently, silver NPs don't disapprovingly consequence feasible cell don't naturally provoke infectious confrontation (20). Henceforth, AgNPs that combined in frequent procedures like ( tubes material, medicinal procedures besides blister bandages) to defend in contradiction of bacteriological pollution. Ocimum sanctum is regularly secondhand as energetic medication worldwide (21). In frequent democracies, this rosemary is lengthily castoff for cookery energies interest, tastes, indispensable oils besides helpful proposals(22). Leaves, flowering parts of $O$. sanctum that typically rummage-sale to (tolerance temperature, seasickness, abdominal spasms gastroenteritis, migraines, alertness, desolation, gonorrhea dysentery, long-lasting diarrhea besides weariness). External suggestions include conduct of ( skin condition, forfeiture of odor, bug tastes, traitor tastes besides skin infections) (23). Added conspicuously, documented for (thoughtful anti-lipid emic, anti-cholesterol, anti-microbial besides anti-diabetic )properties $(24,25,26,27)$. This exercise intended at developing a diffident, ecological approachable besides custody present green interaction process for synthesis of NPs with Ocimum sanctum leaf excerpts, as normal plunging agent. 


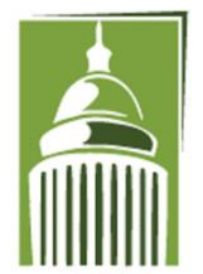

AR F
Global Proceedings Repository

American Research Foundation

ISSN 2476-017X

Available online at http://proceedings.sriweb.org

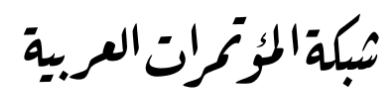

http://arab.kmshare.net/

\section{3-Substantial \& Procedures}

\section{3-1Ocimum sanctum substantial provision}

Plant leaf from (Ocimum sanctum) remained composed commencing native allotment ,remained disemboweled, in-flight dry to (ten days), then earmarked in oven at (60C) to one day then crumpled for well precipitate .

\section{3-2Mycological separates}

These mycological separates ( Bipolaris Curvularia, Magnaporthe oryzae, Phomopsid asparagicola, Alternate alternate, Geotrichum amycelicum, Fusarium circinatum, Aspergillus flavus, Rizoctonia oryzae, Penicillium digitatum, Macrophomina limbalis). Be situated gifted from Department of biology, AL- Mustansarya University,Iraq. Completely isolates full-grown at $(25 \mathrm{C}$ )for seven days. Formerly Disk $(0.5 \mathrm{~mm})$ of every isolates elated on or after fungi grow through use (PDA) medium altogether plates protected in $25 \mathrm{C}$ for one week.

\section{3-3Provision $O$. sanctum excerpt}

(10) $\mathrm{g}$ from leaf powder were placed in (100) $\mathrm{ml}$ of (90\%) methanol in glass flask, kept back on a rotary shaker at $(180-200) \mathrm{rpm}$ for one day . After this time the mixture filtered from side to side done four sheets from textile then centrifuge for (500) rpm to (10) min. supernatant composed, solvent was disappeared and kept to $4{ }^{\circ} \mathrm{C}$ appearance close-fitting decanters to supplementary trainings.

\section{3-4Production AgNPs}

Ag nitrate additional for the leaf excerpt toward create latest solution (200) $\mathrm{ml}$ and centrifuged at (18.000)rpm to $30 \mathrm{~min}$. The composed tablets kept at (40)c. The supernatant heated at $(500){ }^{\circ} \mathrm{C}$ to $(950)^{\circ} \mathrm{C}$. Modification in solution color experiential throughout heating system procedure.

\section{3-5Preoccupation Ranges}




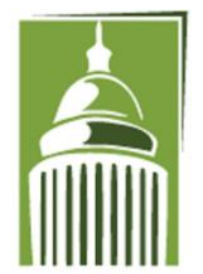

AR F
Global Proceedings Repository

American Research Foundation

ISSN 2476-017X

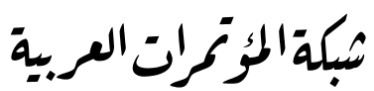

http://arab.kmshare.net/

Available online at http://proceedings.sriweb.org

Attractiveness available to formation silver NPs, (UV-VIS) preoccupation ranges from prepared $\mathrm{Ag}$ explanation reported consuming spectrophotometer in contradiction of . Decrease of AgNPs experiential via sporadic sample from aqueous component . Afterward addition from leaf excerpt for silver nitrate , Preoccupation reserved in varied period intermezzos up to (24) hours. The dated intermezzos were reserved as (10 , 40,60 ,24) h. Latest interpretation reserved in $48 \mathrm{~h}$ after reaction beginning ,through conniving ( UV-VIS) range that determination from response period were (200-900) nanometer.

\section{3-6Provision of silver NPs suspension}

(1)g from silver NPs dissolved trendy in Distell water to create stock solution $)$. $(20,40,60) \mu \mathrm{g} / \mu \mathrm{l}$ of silver NPs were prepared then use for completely experimentations.

\section{3-7Calculation of Anti-fungal activity:}

The anti-fungal conceivable of bio synthesized of silver NPs was studied .(5) $\mathrm{ml}$ of silver NPs in many concentrations $(100,200,300)$ $\mathrm{mg} / \mathrm{ml}$ in disinfected D.W. was additional into (5) $\mathrm{ml}$ of sterile culture media beforehand hardened. Concoction decanted into disinfected plates. wheels including just sterile culture media were also cautious. Petri dishes protected in murky in (28) $)^{\circ} \mathrm{C}$ to (48) h, afterward that, agar plugs(5)mm of growing fungal mycelia, The plates were incubated at $(25)^{\circ} \mathrm{C}$ for (5) days. The spontaneity efficiency of silver NPs for all strains were envisioned.

\section{4-Consequences \& Conversation}

Decrease of silver ion for silver NPs concluded interaction to plant extracts might be followed through color modification. Silver NPs exhibition from yellow to brown color in aqueous resolution for reason that of excitation from superficial Plasmon resonance phenomenon piercing, modification of unique solution color ended examination from silver NPs formation by therapeutic leaf extracts references to production of Ag NPs (28). In floras probability of decrease of silver nitrate to silver NPs demonstrated shortsighted device supposed for 


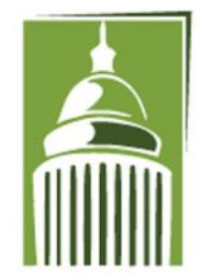

AR F
Global Proceedings Repository

American Research Foundation

ISSN 2476-017X

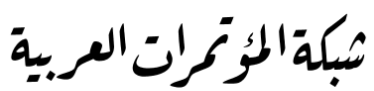

http://arab.kmshare.net/

Available online at http://proceedings.sriweb.org

remain glycolysis ,that comprises $\mathrm{CO}_{2}$ obsession by convenience from sunshine, wherever Complex carbohydrate intended (29).

UV obvious absorption spectrum of silver NPs reported at intermezzo for (10 min., $20 \mathrm{~min}$., $60 \mathrm{mi}$., $24 \mathrm{~h}$. and $48 \mathrm{~h}$ ). beginning twitch for response. absorption band experimental in (400-430) $\mathrm{nm}$. Consequences talk about manufacture of silver NPs followed rapidly inside (10) min., happening half to rapid bio synthesis from Ag NPs , preoccupation highest distended through period greater.

Later (24) h. of incubation, extreme absorbance was experiential and it sustained unending after (48) h of reaction. Owed to superficial plasmon resonance (SPR) phenomena, reverberating peak occurs at a variety of wavelengths for frequent Nano particles combination and version to attitude of character extreme wavelength, is engrossed at echoing wavelengths (30). Previous exercises suggest that a traditional silver NPs protests (SPR )designs at wavelengths in the variety of (400-480)nm. SPR pattern of metallic Nano particles be depending on the stabilization particle, procedure and possibility of particles present in the medium or upon interior particle taciturnity and nearby media $(31,32)$.

Natural production from NPs through organic harvests chiefly herbal excerpts complicated maintenance from many specialists toward regulator infections. In this project, the effect of silver NPs on pathogenic molds was inspected. Additional the Nano particles manufactured by green direction were create to be tremendously toxic in contradiction of 10 species of fungi (Table 1). The reserve of the mycelia growing by silver NPs at many attentions were ordinary measured and photographed for completely the confirmed fungi. Consequences in (Table 1) presented alterations in anti-fungal activities of silver NPs diagonally qualified molds besides many concentrations. Among practiced molds, extreme reserve percentage $(96.1,94.2,93.5 \%)$ was experimental by ( Rizoctonia oryzae, Alternaria alternata , Aspergillus flavus) correspondingly at $(300) \mathrm{mg} / \mathrm{mL}$ of the silver NPs while lowest inhibition percentage $(11.9,14.7,17.3 \%)$ seen by (Phomopsid asparagicola, Penicillium digitatum , Magnaporthe limbalis) correspondingly . 
Global Proceedings Repository

American Research Foundation

ISSN 2476-017X

Available online at http://proceedings.sriweb.org

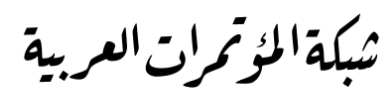

http://arab.kmshare.net/

Table(1): Anti-fungal action of Ag NPs creation using $O$. sanctum .

\begin{tabular}{|c|c|c|c|}
\hline \multirow{2}{*}{ Fungi } & \multicolumn{3}{|c|}{ Inhibition of radial growth(\%) } \\
\cline { 2 - 4 } & $(100) \mu \mathrm{g} / \mu \mathrm{l}$ & $(\mathbf{2 0 0}) \boldsymbol{\mu g} / \boldsymbol{\mu l}$ & $(300) \mu \mathrm{g} / \mu \mathrm{I}$ \\
\hline B. Curvularia & 21.4 & 50.9 & 81.7 \\
\hline M. oryzae & 17.3 & 46.7 & 76.8 \\
\hline P. asparagicola & 11.9 & 31.9 & 69.3 \\
\hline A. alternate & 34.1 & 71.2 & 94.2 \\
\hline G. amycelicum & 25.6 & 54.8 & 89.1 \\
\hline F. circinatum & 20.4 & 41.1 & 82.1 \\
\hline A. flavus & 35.9 & 67.1 & 93.5 \\
\hline Rizoctonia oryzae & 42.4 & 76.3 & 96.1 \\
\hline P. digitatum & 14.7 & 28.9 & 64.9 \\
\hline M.limbalis & 21.3 & 51.1 & 88.9 \\
\hline
\end{tabular}

Anti-fungal actions of bio synthesized silver NPs were assessed in contradiction of pathogenically molds. That arrangement from substantial happening anti-microbial actions from silver NPs biological synthesized through inclusive diversity of plant kinds (33). Significances in present exercise suggest that $O$. sanctum leaves extract capacity adore convinced amalgams like (Thymol, Carvacrol ) phenolic aromatic combinations.

the composites remain healthy documented by way of influential antifungal possessions (34). they propose for attain in vivo research for detection obtainable supplementary statistics around act from fungi contagions. Nano particles have highest authoritative fragment in 


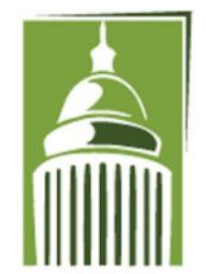

AR F
Global Proceedings Repository

American Research Foundation

ISSN 2476-017X

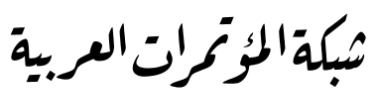

http://arab.kmshare.net/

Available online at http://proceedings.sriweb.org

replacement of increasing managers hysterics to toxicity(35). The healthy interfering of Ag NPs with Thiel group of active enzymes and delay enzyme activities(36), or through duplication of (DNA) is overfilled as soon as the fungal cell simple to ionic silvers(35). The care of Nano particles can major to the denaturation the building of the fungal proteins consequent in excess owing to stabilization of Nano particle as a colloid in medium. The Nano particle naturally intended by plant have great toxicity on medication unaffected microbes since they have extreme credible in bio-medicine examination extents, like the investigations that achieved on Allium cepa (36) Argimone mexicana(37) and Artocarpus heterophyllus (38).

\section{Referanseses:}

1-Ahmad T, Wani IA, Manzoor N, Ahmed J, Asiri AM (2013).Biosynthesis, structural characterization and antimicrobial activity of gold and silver nanoparticles. Colloid Surf B 107:227-234.

2-Kim JH. (2006).Nano silver chemotherapeutic agents and its applications. News Inf Chem Eng ;22:655-60.

3-Berger TJ, Spadaro JA, Chapin SE, Becker RO. (1976).Electrically generated silver ions: quantitative effects on bacterial and mammalian cells. Antimicrob Agents Chemother ;9:357-8

4-Buffet, P. E., Richard, M., Caupos, F., Vergnoux, A., Perrein-Ettajani, H., Luna-Acosta, A., et al. (2013). A mesocosm study of fate and effects of $\mathrm{CuO}$ nanoparticles on endobenthic species (Scrobicularia plana,

Hediste diversicolor). Environ. Sci. Technol. 47, 1620-1628.

5-Aarré, M., Gajda-Schrantz, K., Kantiani, L., and Barceló, D. (2009).

Ecotoxicity and analysis of nanomaterials in the aquatic environment.

Anal. Bioanal. Chem. 393, 81-95.

6-Gambardella, C., Aluigi, M. G., Ferrando, S., Gallus, L., Ramoino, P., Gatti, A. M., et al. (2013). Developmental abnormalities and changes in cholinesterase activity in sea urchin embryos and larvae from sperm exposed to engineered nanoparticles. Aquat.Toxicol. 130-131, 77-85. 


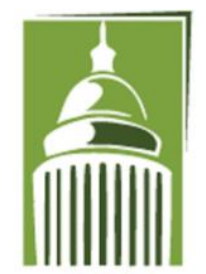

AR F

\section{Global Proceedings Repository \\ American Research Foundation}

ISSN 2476-017X

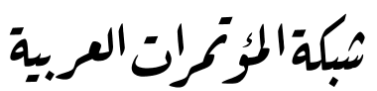

http://arab.kmshare.net/

Available online at http://proceedings.sriweb.org

7-Gomes, S. I. L., Scott-Fordsmand, J. J., and Amorim, M. J. B.

(2015).Cellular energy allocation to assess the impact of nanomaterials on soil invertebrates (Enchytraeids): the effect of $\mathrm{Cu}$ and $\mathrm{Ag}$. Int. J. Environ. Res. Public Health 12, 6858-6878.

8-Gomes, S. I., Murphy, M., Nielsen, M. T., Kristiansen, S. M., Amorim, M. J., and Scott-Fordsmand, J. J. (2015). Cu-nanoparticles ecotoxicityexplored and explained? Chemosphere 139, 240-245.

9-Gomes, S. I., Novais, S. C., Gravato, C., Guilhermino, L., ScottFordsmand, J. J., Soares, A. M., et al. (2012). Effect of Cu-nanoparticles versus one $\mathrm{Cu}$-salt: analysis of stress and neuromuscular biomarkers response in Enchytraeus albidus (Oligochaeta). Nanotoxicology 6, 134143.

10-Gonçalves, M. F. M., Gomes, S. I. L., Scott-Fordsmand, J. J., and Amorim, M. J. B. (2017). Shorter lifetime of a soil invertebrate species when exposed to copper oxide nanoparticles in a full lifespan exposure test. Sci. Rep. 7:1355.

11-Heinlaan, M., Ivask, A., Blinova, I., Dubourguier, H. C., and Kahru, A. (2008). Toxicity of nanosized and bulk $\mathrm{ZnO}, \mathrm{CuO}$ and $\mathrm{TiO} 2$ to bacteria Vibrio fischeri and crustaceans Daphnia magna and Thamnocephalus platyurus. Chemosphere 71, 1308-1316.

12- Gavhane AJ, Padmanabhan P, Kamble SP and Jangle SN (2012). Synthesis of silver nanoparticles using extract of Neem leaf and Triphala and evaluation of their antimicrobial activities. International Journal of Pharma and Bio Sciences 3(3) 88-100.

13-Sahu PK, Giri DD, Singh R, Pandey P, Gupta S, Shrivastava AK, Kumar A, PandeyKD. (2013). Therapeutic and medicinal uses of Aloe vera: a review.Pharmacology \&Pharmacy4:599-610.

14-Yallappa, S.; Manjanna, J.; Dhananjaya, B.L. (2015).Phytosynthesis of stable $\mathrm{Au}, \mathrm{Ag}$ and $\mathrm{Au}-\mathrm{Ag}$ alloy nanoparticles using J. Sambac leaves extract, and their enhanced antimicrobial activity in presence of organic antimicrobials.Spectrochim. Acta Part A Mol. Biomol. Spectrosc. 137, 236-243. 


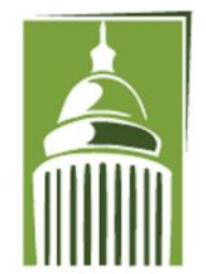

AR F
Global Proceedings Repository

American Research Foundation

ISSN 2476-017X

Available online at http://proceedings.sriweb.org

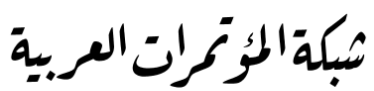

http://arab.kmshare.net/

15-Iram, F.; Iqbal, M.S.; Athar, M.M.; Saeed, M.Z.; Yasmeen, A.; Ahmad, R. (2014).Glucoxylan-mediated green synthesis of gold and silver nanoparticles and their phyto-toxicity study. Carbohydr. Polym. 104, 29-33.

16-Vijayaraghavan, K.; Nalini, S.; Prakash, N.U.; Madhankumar, D.(2012). One step green synthesis of silvernano/microparticles using extracts of Trachyspermum ammi and Papaver somniferum. Colloid Surf B Biointerfaces , 94, 114-117.

17-Nazeruddina, G.M.; Prasada, N.R.; Prasadd, S.R.; Shaikha, Y.I.; Waghmareb, S.R.; Adhyapak, P. (2000).Coriandrum sativum seed extract assisted in situ green synthesis of silver nanoparticle and its antimicrobial activity.Ind. Crops Prod. 60, 212-216 .

18-Joerger, R.; Klaus, T.; Granqvist, C.G.(2000). Biologically produced silvercarbon composite materials for optically functional thin-film coatings. Adv. Mater. 12, 407-409.

19-Fayaz, A.M.; Balaji, K.; Girilal, M.; Yadav, R.; Kalaichelvan, P.T.; Venketesan, R. (2010).Biogenic synthesis of silver nanoparticles and their synergistic effect with antibiotics: A study against gram-positive and gram-negative bacteria. Nanomedicine: Nanotechnology. Biol. Med. 6, 103-109.

20-Kowshik, M.; Ashtaputre, S.; Kharrazi, S.; Vogel, W.; Urban, J.; Kulkarni, S.K.; Paknikar, K.M. (2003).Extracellular synthesis of silver nanoparticles by a silver-tolerant yeast strain MKY3. Nanotechnology , 14,95 .

21-Otari, S.V.; Patil, R.M.; Ghosh, S.J.; Pawar, S.H. (2014).Green phytosynthesis of silver nanoparticles using aqueous extract of Manilkara zapota (L.) seeds and its inhibitory action against Candida species. Mater. ,Lett. 116:367-369.

22-Annamalai, J.; Nallamuthu, T. (2016).Green synthesis of silver nanoparticles: Characterization and determination of antibacterial potency. Appl. Nanosci. 6, 259-265. 


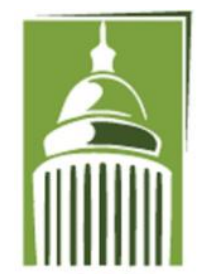

AR F
Global Proceedings Repository

American Research Foundation

ISSN 2476-017X

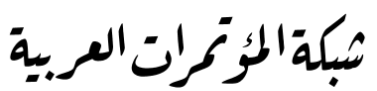

http://arab.kmshare.net/

Available online at http://proceedings.sriweb.org

23-Ingle, A.; Gade, A.; Pierrat, S.; Sonnichsen, C.; Rai, M.(2008).

Mycosynthesis of silver nanoparticles using the fungus Fusarium acuminatum and its activity against some human pathogenic bacteria. Curr. Nanosci. 4,141-144.

24-Liu, J.Y.; Sonshine, D.A.; Shervani, S.; Hurt, R.H. (2010).Controlled release of biologically active silver from nanosilver surfaces. ACS Nanotechnol. 4, 6903-6913.

25-Kim, S.; Choi, J.E.; Choi, J.; Chung, K.H.; Park, K.; Yi, J. (2009).Oxidative stress-dependent toxicity of silver nanoparticles in human hepatoma cells. Toxicol. Vitro, 23, 1076-1084.

26-Shrivastava, S.; Bera, T.; Roy, A.; Singh, G.; Ramachandrarao, P.; Dash, D. (2007).Characterization of enhanced antibacterial effects of novel silver nanoparticles. ACS Nanotechnol. 3, 1357-1364.

27-Yu, S.J.; Yin, Y.G.; Liu, J.F.(2013). Silver nanoparticles in the environment. Environ. Sci. 15, 78-92.

28-Feng, Q.L.; Wu, J.; Chen, G.Q.; Cui, F.Z.; Kim, T.N.; Kim, J.O.(2010). A mechanistic study of the antibacterial effect of silver ions on Escherichia coli and Staphylococcus aureus. J. Biomed. Mater. Res. 52, 662-668.

29-Morones, J.R.; Elechiguerra, J.L.; Camacho, A.; Holt, K.; Kouri, J.B.; Ramfrez, J.T.; Yacaman, M.J. (2005).The bactericidal effect of silver nanoparticles. Nanotechnology . 16, 2346-2353.

30-Vertelov, G.K.; Krutyakov, Y.A.; Efremenkova, O.V.; Olenin, A.Y.; Lisichkin, G.V. (2008).A versatile synthesis of highly bactericidal Myramistin stabilized silver nanoparticles. Nanotechnology , 19, 355707.

31-Melaiye, A.; Sun, Z.; Hindi, K.; Milsted, A.; Ely, D.; Reneker, D.H.; Tessier, C.A.; Youngs, W.J.(2005). Silver (I)imidazole cyclophane gemDio complexes encapsulated by electrospun tecophilic nanofibers: Formation of nanosilver particles and antimicrobial activity. J. Am. Chem. Soc. 127, 2285-2291. 


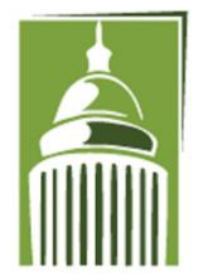

AR F
Global Proceedings Repository

American Research Foundation

ISSN 2476-017X

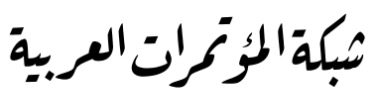

http://arab.kmshare.net/

Available online at http://proceedings.sriweb.org

32-Tian J, Wong KK, Ho CM, Lok CN, Yu WY, Che CM, Chiu JF and Tam PK (2007). Topical delivery of silver nanoparticles promotes wound healing. ChemMedChem 2(1) 171-80 .

33-Tripathy A, Raichur AM, Chandrasekaran N, Prathna TC and Mukherjee A (2009). Process variables in biomimetic synthesis of silver nanoparticles by aqueous extract of Azadirachta indica (Neem )leaves. Journal of Nanoparticle Research 12(1) 237-246 .

34-Wiley BJ, Im SH, Li ZY, Mclellan J, Siekkenen A and Xia Y (2006). Maneuvering the surface plasmon resonance of silver nanostructures through shape-controlled synthesis. Journal of Physical Chemistry B 110(32) 15666-15675.

35-Jha, A.K and Prasad, K (2010). Green synthesis of silver nanoparticles using Cycas leaf, Int. J. Green Nanotech.Phy. Chem. 1:110-117

36-Khandelwal, N. Singh, A. Jain, D. Upadhyay, M.K and Verma, H.N (2010). Green synthesis of silver nanoparticles using Argimone maxicana leaf extract and evaluation of their activity, Digest. J. Nanomater.

Biostruct. 5:483-489.

37-Kim, J.S. Kuk, E. Yu, K.N. Kim, J.H. Park, S.J. Lee, H.J. Kim, S.H.

Park, Y.K. Park, C.Y. Huwang, C.Y. Kim,Y.K. Lee, Y.S. Jeong, D.H and Cho, M.H (2007). Antimicrobial effects of silver nanoparticles, Nanomed Nanotechnol. Biol. Med. 3:95-101 .

38-LingaRao, M and Savithramma, N (2011). Biological synthesis of silver nanoparticles synthesized by using stem extract of Svensonia hyderobadensis (Walp.) Mold—a rare medicinal plant. Res Biol3:41-47 . 